\title{
甲状腺機能元進症術後再発の 1 再手術例
}

\section{一術後再発に対する検討一}

\begin{tabular}{|c|c|c|c|c|c|c|c|c|}
\hline \multicolumn{9}{|c|}{ 琉球大学医学部第 1 外科（主任：正 } \\
\hline 4 & 口 & 宝 & 正 & & 義 之 & 武 & 藤 良 & \\
\hline & 間 & 章 & 栗 & 原 & 公太郎 & 玉 & 城 & \\
\hline & & & & & & & & \\
\hline
\end{tabular}

甲状腺機能え進症における甲状腺严全摘術後再発症例に対する治療は, ${ }^{131}$ I 療法や抗 甲状腺剤などによる保存的㞠法が主に行われ，合併症が起こり易いなどの理由で再手術 は行らべきでないとされている，しかし，今回，同症例に対して再手術を施行し好成績 を得た. 症例は 39 歳の女性で 7 年前にパセドウ病に上る甲状腺機能克進症の診断で甲状 腺垔全摘術を施行された。術後 4 年目より再発, 抗甲状腺剤を投与されていたが，本年 3 月手術希望にて入院，再手術を施行し残存甲状腺量は $5 \mathrm{~g}$ とした。術後経過は良好で, この様な症例に対する再手術はその適応，適切な手術操作を行うことで満足のゆく結果 が得られる.

索引用語：甲状腺機能六進症, 甲状腺亚全摘後の再手術

\section{緒言}

甲状腺機能九進症の術後再発に対する再手術は，合 併症が起り易いなどの理由で131I療法等の保存的治療 を行わ机るとが多い。しかし今回, 術後 7 年目の再 発症例に対し再手術を行い好成績を得たので, 再発に 関与する諸因子及び再発症例に対する治療を検討し報 告する.

患者 : 39歳, 女性.

\section{症例}

主訴：頸部尰瘤.

家族歴：特記事項なし。

既往歴：昭和 54 年, バセドウ病による甲状腺機能え 進症にて甲状腺要全摘術。

現病歴：昭和58年に頸部隀瘤，動悸が出現し，再発 と診断され抗甲状腺剤および 受けていた。しかし，頸部尰瘤が軽快しないため，昭 和61年 3 月に当科で受診, 手術目的で入院した。

入院時現症：身長 $156 \mathrm{~cm}$, 体重 $81 \mathrm{~kg}$ ，脈拍 $75 /$ 分 - 整, 血圧 $140 / 80 \mathrm{mmHg}$, 皮店湿潤・左前頸部に $3 \times 2 \mathrm{~cm}$, 右 前頸部に $4 \times 3 \mathrm{~cm}$ と尰大した甲状腺を認めた，表面平 滑, 弾性硬で左葉と右葉は独立しており連続性を有し

昭和61年12月12日受付 62 年 2 月19日採用

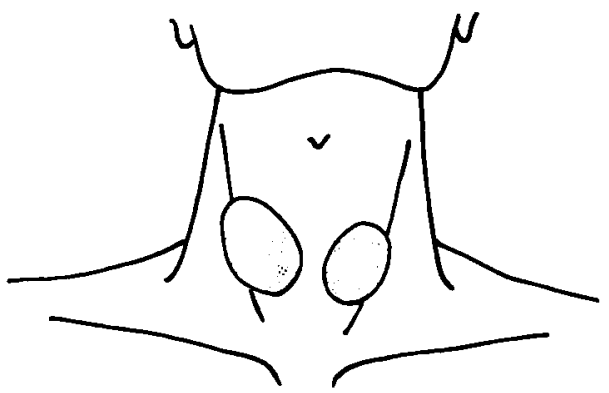

図 1 入院帱局所所見：甲状腺は表面平清，弾性硬で 左葉と右葉が独立している。

ていない（図 1)，thrill は触れず，頸部血管雑音は僡 取されなかった。

入院時検查成縝：末梢血液像および血液生化学検查 に異常はなく，甲状腺機能ではトリョードサイロニン (以下 $\mathrm{T}_{3}$ ) $364.4 \mathrm{ng} / \mathrm{dl}$, サイロキシン (以下 $\mathrm{T}_{4}$ ) 19.0 $\mu \mathrm{g} / \mathrm{dl}$ と高值を示し, TSH は1. $0 \mu \mathrm{u} / \mathrm{ml}$ であった（表 1).頸部軟線 X線写真では甲状腺の看大がみられた。 甲状腺 ${ }^{99 m} \mathrm{Tc}$ シンチダラムでは増大した甲状腺への取 込みがみられた(図 2)。超音波ェコー像は気管の左右 に独立して，堌大した甲状腺がみられる（図3）。

以上の所見より甲状腺機能六進症術後再発の診断て 
表 1 入院時検查成綪

\begin{tabular}{cc|cc}
\hline 末梢血液像 & & 生化学検査 & \\
WBC & $7.8 \times 10^{3} / \mathrm{mm}^{3}$ & GOT & $34 \mathrm{IU} / 1$ \\
$\mathrm{RBC}$ & $499 \times 10^{4} / \mathrm{mm}^{3}$ & $\mathrm{GPT}$ & $68 \mathrm{IU} / 1$ \\
$\mathrm{Hb}$ & $15 \mathrm{~g} / \mathrm{dl}$ & $\mathrm{TP}$ & $7.2 \mathrm{~g} / \mathrm{dl}$ \\
$\mathrm{Hct}$ & $43.1 \%$ & $\mathrm{Alb}$ & $4.2 \mathrm{~g} / \mathrm{dl}$ \\
$\mathrm{Plt}$ & $30 \times 10^{4} / \mathrm{mm}^{3}$ & $\mathrm{Na}$ & $138 \mathrm{mEq} / 1$ \\
甲状腺機能 & & $\mathrm{K}$ & $4 \mathrm{mEq} / 1$ \\
$\mathrm{~T}_{3}$ & $364.2 \mathrm{ng} / \mathrm{dl}$ & $\mathrm{Cl}$ & $101 \mathrm{mEq} / 1$ \\
$\mathrm{~T}_{\mathbf{1}}$ & $19.0 \mu \mathrm{g} / \mathrm{dl}$ & $\mathrm{Ca}$ & $4.7 \mathrm{mEq} / 1$ \\
$\mathrm{TSH}$ & $1.0 \mu \mathrm{U} / \mathrm{ml}$ & & \\
\hline
\end{tabular}

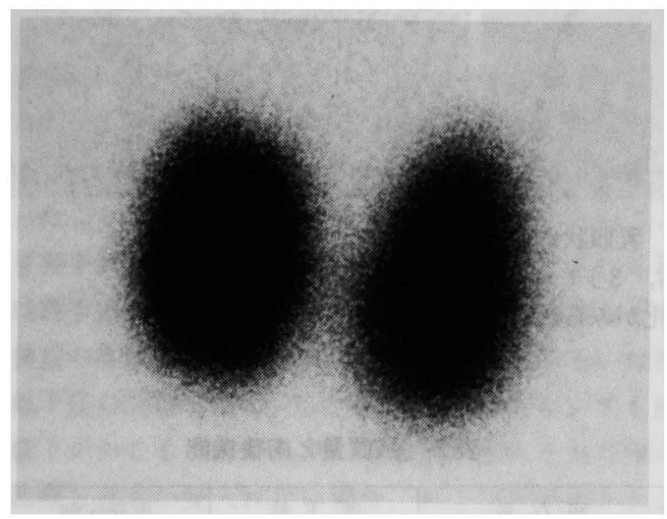

图 2 甲状腺 ${ }^{99 m} T \mathrm{c}$ シンチグラム：増大した甲状腺へ の取込みがみられる。

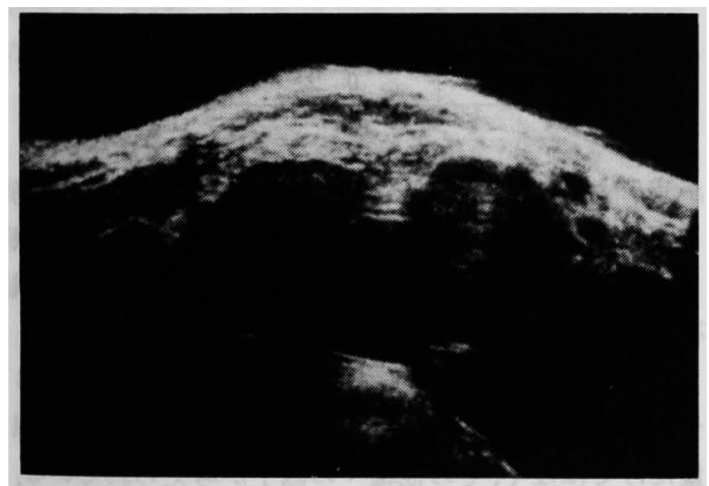

图 3 甲状腺超音波エコー使：気管の左右に独立し

て，腫瘁状に増大した甲状腺両葉がみられる。

Mercazole, Propranolol, Diazepam, 無機ヨード剤の 投与にて術前甲状腺機能コントロールを行い（图4）， 手術を施行した。

手術所見：前回手術と同じ部位に皮切を加えて手術 を行った，前頸筋を正中にて切開し，甲状腺前面創を
経 過
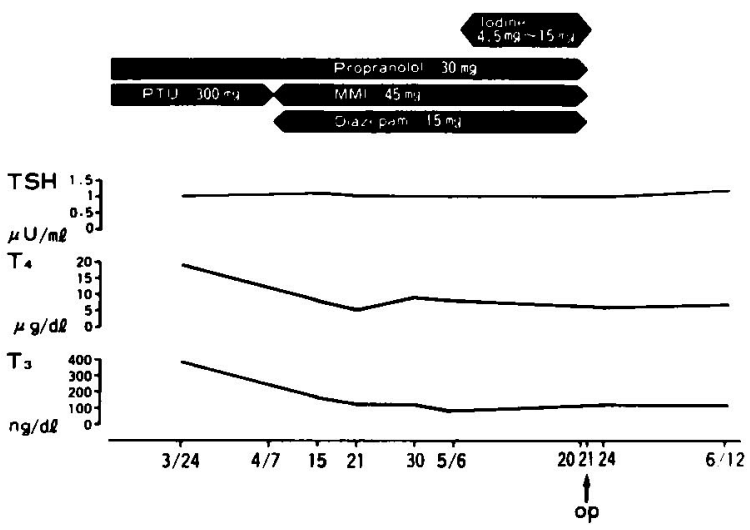

图 4 術前甲状腺譏能コントロール

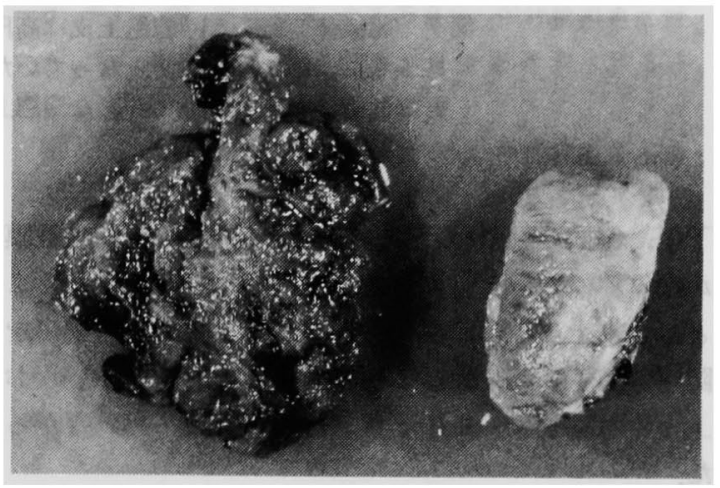

図 5 摘出摽本

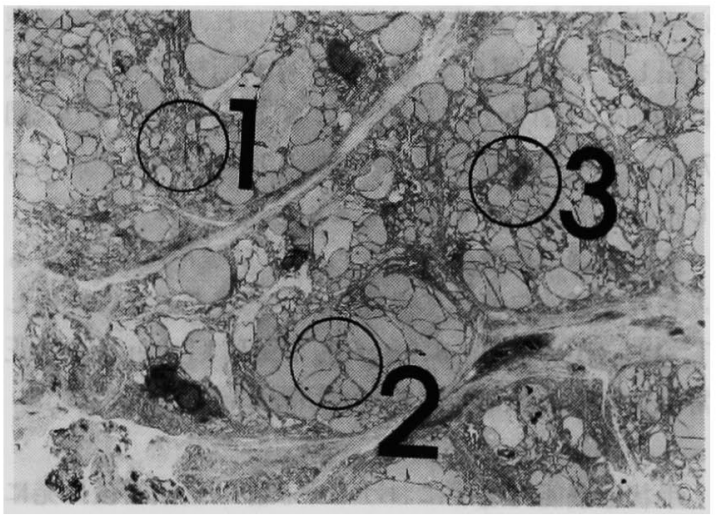

図 6 再発時の組織像：甲状腺全体に結節様な変化が みられ，多様な組織像を呈している（ $\mathrm{HE}, \times 5)$

豩離していくと気管の左右にそれぞれ独立して増大し た甲状腺右葉, 左葉がみられた。状腺に接して上梗， 


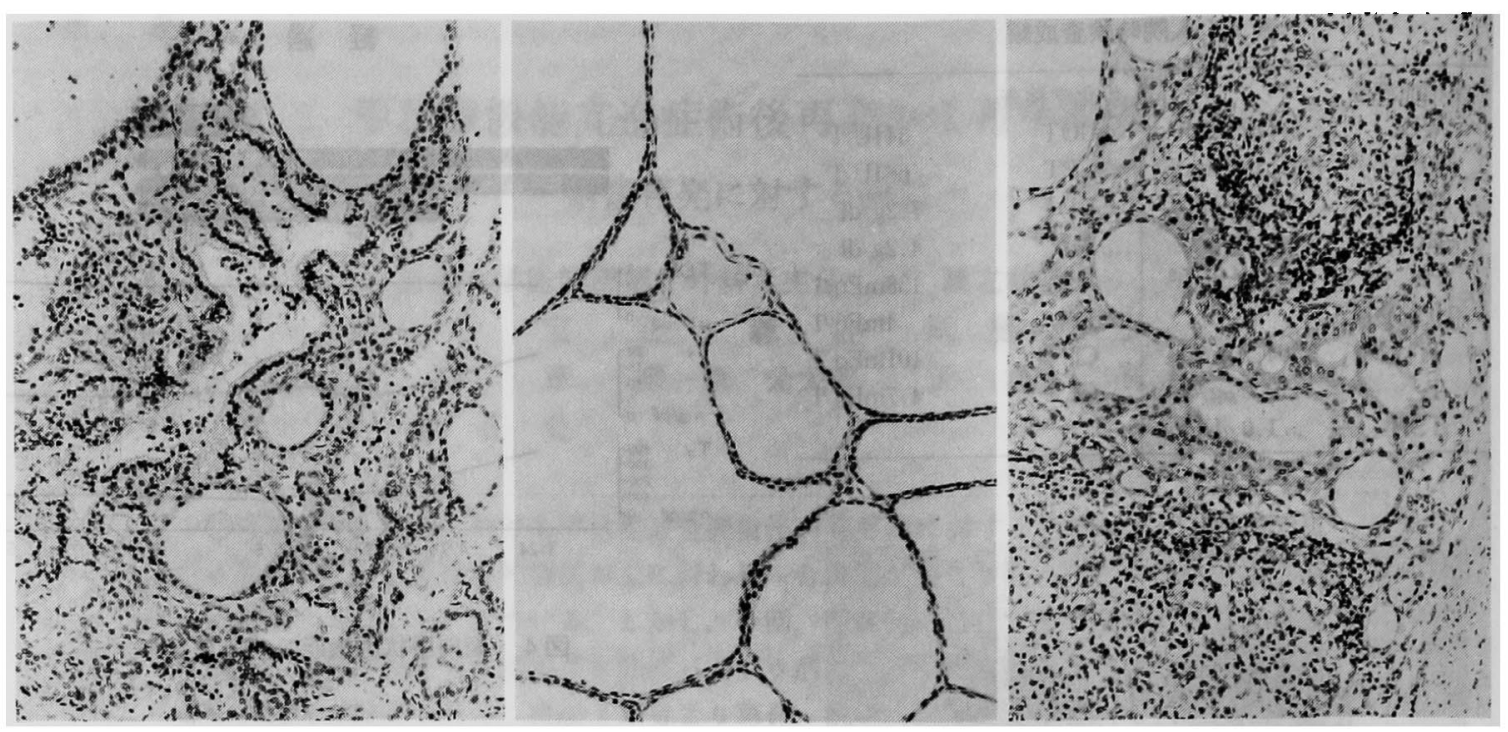

図 7 組織像：〔左，1]琥胞上皮は高円柱状で，乳頭状に増殖していたり，〔中，2〕

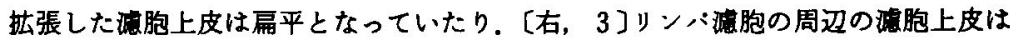
好酸性胞体を有していて多彩な濾胞上皮の变化がみられた。

下極，側面の剥離を行い，側，後，内面の甲状腺被膜 がなるべく残るよらに甲状腺の中心部をえぐり取るこ とにより上皮小体，反回神経の手術操作による損傷を 防ぎ，残存甲状腺量を右 $2 \mathrm{~g}$ ，左 $3 \mathrm{~g}$ ，合計 $5 \mathrm{~g}$ とした。 なお 上下甲状腺動脈，上中下甲状腺静脈は認められなかっ た。

病理組織学的所見：切除甲状腺は右 $4.0 \times 2.5 \mathrm{~cm}$, $3.5 \mathrm{~g}$, 左 $3.3 \times 3.1 \mathrm{~cm}, 4 \mathrm{~g}$ であった (図 5 )。組織学的に は甲状腺全体に結節様の変化がみられ，多様な組織像 を呈している(图6)，濾胞上皮は高円柱状で，乳頭状 に增殖し（図 7-1），払張した滤胞上皮は扁平で（図 7-2），リンパ濾胞の周辺の濾胞上皮は好酸性胞体を有 していて多彩な滤胞上皮の变化がみられた（図 7-3）.

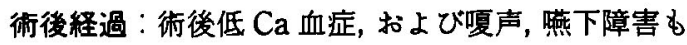
みられず程過良好にて退院した，術後 7 カ月を経過し $\mathrm{T}_{3} 124.0 \mathrm{ng} / \mathrm{dl}, \mathrm{T}_{4} 8.9 \mu \mathrm{g} / \mathrm{dl}, \mathrm{TSH}$ は $1.0 \mu \mathrm{u} / \mathrm{ml}$ と正 常値を示し，頸部腯瘤もなく順調に経過している.

\section{考 案}

甲状腺機能穴進症に扣ける甲状腺覀全摘術後再発に 最む大きく関与する因子は，初回手術時の甲状腺残存 量であると言われている，残存量が適切でなく多すぎ た場合，いわゆる不完全治瘾例では高率に再発がみら れ，初回手術時の甲状腺残存量が増加するのにしたが い再発率も高くなる(表 2)) $)^{1) \sim 8 ｝ \text { ．また，甲状腺残存量 }$
表 2 残罾皇と術後機能

\begin{tabular}{c|c|c}
\hline 残 存量 & 低下症 & 再発症例 \\
\hline $2 \sim 4 \mathrm{~g}$ & $42.8 \%$ & $3.3 \%$ \\
\hline $3 \sim 6 \mathrm{~g}$ & $54 \%$ & $4.1 \%$ \\
\hline $7 \sim 9 \mathrm{~g}$ & $10.0 \%$ & $7.0 \%$ \\
\hline $10.1 \sim 20 \mathrm{~g}$ & $0.7 \%$ & $30.4 \%$ \\
\hline $20 \mathrm{~g} \sim$ & $0 \%$ & $50 \%$ \\
\hline
\end{tabular}

が減少するのにしたがい術後機能低下症の合併率す高

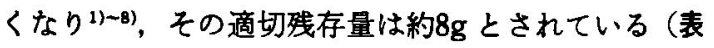
2). 本症例では, 他院で初回手術が行われていて, 残 存量の詳細については不明であった。

しかし，その適切残存量として手術をしても，3 ～9\%の再発がみられ，術媵の再発因子は残存甲状腺 量だけではなく，その他種々の因子が考えられている. その他の再発因子として，佐々木ら9は初回手術時に BMR, ${ }^{131} \mathrm{I}$ 撖取率が高いものに多いとし，原田11は抗サ イログロプリン抗体，抗マイクロソーム抗体が陽性例 のものに多いとしている。 また，伊藤年は術前 TBII (TSH binding inhibiting immunoglobulin) 值と再発 との関係について述へ，術前高値例には再発の㑯向が あり，陰性例は術後機能低下症に陥りやすい傾向があ るので注意が必要であるとしている，組織学的に再手 
行時の甲状腺は淲胞上皮の増殖が特徵的) とされてい るが，初回手術時における組織像では，リンハ球漫潤 およびリンパ滤胞の存在する症例に多いと言ら報告1) や，また逆に，それらには少ないと言ら報告(1) 131る み られ，統一した見解は得られていないようである. 本 症例での再発時の甲状腺組織像は多彩であって, 再発 時の特徽的像とされている濾胞上皮の增殖は散在性で あって，むしろ、リンハ演胞の形成を伴 adenomatous goiter 様の像を示していた。

甲状腺严全摘術後再に対する処置としては，再手術

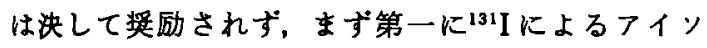
トープ治療が第一選択とされている，第二に妊娠を望 む場合には抗甲状腺剤でのコントロールが望ましいと されている.しかし本症例では患者が娃娠を希望して いること，抗甲状腺戍によるコントロールが困難で あったこと，保存的治療を患者が受入れなかったこと より再手術を施行した. 内科的治療が第一とされる理 由は再手術後における上皮小体，反回神経損傷などの 合併症の危険性および, 再手術後の再々発あるいは機 能低下症の問題である。しかし, ${ }^{131}$ 療法においても機 能低下がおこることがあり，本症例の様にそれら保存 的治療を患者が受入れない場合，扣よび甲状腺が大き くなった場合などは，合併症に十分な注意を払い，慎 重な手術を行らことで再手術により満足のいく結果が 得られる。最後に，再手術時における残存甲状腺量は 佐々木ら9の報告は, $5 \mathrm{~g}$ 位が良いとし, 本症例む彼らに ならって5gとし，良好な成績であった。

結語

甲状腺機能亢進症術後再発に対する再手術を行い好 成績を得た 1 症例を報告した。再手術はその適応と適 切な手術により満足のいく結果が得られる。再手術時 における牫存甲状腺量は $5 \mathrm{~g}$ とした。

\section{女 献}

1) 原田種一：パセドゥ病術後の問題一再発, 機能低 下などに関して一，内分泌外科 $1: 315-320$, 1985

2) Beahrs OA, Sakulsky SB : Surgical thyroidectomy in the management of exophth- almic goiter. Arch Surg $76: 512,1968$

3) Hedley AJ, Chesters MI, et al : Surgical treatment of thyrotoxicosis. Brit Med J 28 : 519, 1970

4) 伊藉国彦: 外科的治療. 内科シリーズ No.5, 六七 ドゥ病のすへてて, 鎮目和夫編, p189, 南江堂, 東京。 1971

5）阵粸力男：甲状腺機能六進症の外科的治療。甲状 腺機能六進症の基碟と臨床, 山田隆司, p133, 医歯 薬出版, 東京, 1973

6) Michie WM, Pegg CAS, Bewsher PD: Prediction of hypothyroidism after partial thyroidectomy for thyrotoxicosis. Brit Med J 1 : 13, 1972

7) Caswell HT, Maier WP: Result of surgical treatment for thyrotoxicosis. SSurg Gyn Obst $134: 218,1972$

8）宮川 信, 春日好雄, 金子源吾他：甲状腺知患に対 士る内分泌外科の現況，内分泌外科 $3: 399$ $-406,1986$

9）传々木純，島田克己，加藤典博他：甲状腺機能穴進 症術后再発に対する再手術，日外会誌 81 ： $78-87,1980$

10）伊藤國彦：バセドウ病の病因論と外科的治療, 内 分泌外科 $1: 301-307,1985$

11) Levitt $T$ : Evaluation of the toxic thyroid gland. A clinical and pathological study based on 2114 thyroidectomies. Lancet II : 843, 1962

12) Hargreaves AWM, Graner $A$ : The significance of lymphocytic infiltration of the thyroid gland in thyrotoxicosis. Brit J Surg 55 : 543, 1968

13) Welsum MV, Feltkamp TEW, DeVreis MJ, et al : Hypothyroidism after thyroidectomy for Graves'disease: A serch for and explanation. Brit Med J 28: 755, 1974

14）伊藤悠基夫：バセドウ病術前・術後の処置と問題 点, 内分泌外科 $1: 309-313,1985$

15）深谷月泉, 山本恵一, 上山武史他：再発性甲状腺機 能元進症の再手術の経験, 外科 $37: 47-51,1975$ 


\section{REOPERATION IN PATIENTS WITH RECURRENT HYPERTHYROIDISM AFTER THYROIDECTOMY FOR HYPERTHYROIDISM}

Shigeru DEGUCHI, Yoshiyuki SHO, Kotaro KURIHARA, Yoshihiro MUTO, Akira HOKAMA, Satoshi TAMAKI and Masafumi NOHARA 1st Departmen tof Surgery, Ryukyu University School of Medicine

Reoperation of recurrent hyperthyroidism after thyroidectomy for thyrotoxicosis is an unsettled matter because the surgical techique is much more difficult and postoperative complications occur more frequently. The case reported here is a patient who has been surgically treated and pursued a good postoperative course after reoperation.

The patient was a 39-year-old female who was admitted for reoperation of recurrent hyperthyroidism 7 years after thyroidectomy for thyrotoxicosis. On admission, her thyroid was enlarged and the thyroid function placed her in a condition of thyrotoxicosis. Following the control of thyrotoxicosis, thyroidectomy was performed the residual thyroid tissue weighed $5 \mathrm{gm}$. Her postoperative course was uneventful and she has been doing well with no evidence of recurrent thyrotoxicosis or postoperative hypothyroidism. 